\title{
Integrated Approach for Detection of Nonculturable Cells of Ralstonia solanacearum in Asymptomatic Pelargonium spp. Cuttings
}

\author{
E. Marco-Noales, E. Bertolini, C. Morente, and M. M. López
}

Centro de Protección Vegetal y Biotecnología. Instituto Valenciano de Investigaciones Agrarias (IVIA). Carretera Moncada-Náquera km 4.5, 46113 Moncada, Valencia, Spain. First and second authors contributed equally. Accepted for publication 12 May 2008.

\section{ABSTRACT}

Marco-Noales, E., Bertolini, E., Morente, C., and López, M. M. 2008. Integrated approach for detection of nonculturable cells of Rastonia solanacearum in asymptomatic Pelargonium spp. cuttings. Phytopathology 98:949-955.

Ralstonia solanacearum (biovar 2, race 3) is a soil and water-borne pathogen that causes serious diseases in several solanaceous hosts. It can also infect geranium plants, posing an important threat to their culture when latently infected cuttings are imported from countries where the pathogen is endemic. $R$. solanacearum can be present in very low numbers in asymptomatic geranium cuttings, and/or in a particular stressed physiological state that escapes direct isolation on the solid media usually employed. Consequently, an integrated protocol has been developed to analyze asymptomatic geranium cuttings routinely. The first screening tests include isolation and co-operational-polymerase chain reaction (Co-
PCR), based on the simultaneous and co-operational action of three primers from 16S rRNA of $R$. solanacearum. This method was selected as the most sensitive one, able to detect only $1 \mathrm{cell} / \mathrm{ml}$ including nonculturable cells. When isolation is negative but Co-PCR is positive, the bioassay in tomato plants is proposed, since stressed bacterial cells or those present in low numbers that do not grow on solid media can be recovered from inoculated tomato plants and retain pathogenicity. This methodology has been demonstrated to be useful and has allowed us to assess the relevance of the physiological status of bacterial cells and its implications in detection. It also reveals the risk of introducing $R$. solanacearum through asymptomatic geranium material when relying only on bacterial isolation.

Additional keywords: latent infection, survival.
Ralstonia solanacearum (E. F. Smith) (67) is the causal agent of bacterial wilt and is widespread in tropical, subtropical, and warm temperate regions, leading to serious losses in crops of economic importance $(8,24)$. $R$. solanacearum race 3 (biovar 2 ) is considered a quarantine organism in the European Union (EU) (2) and was among 10 plant pathogens listed in the Agricultural Bioterrorism Protection Act of 2002 in the United States (32). The incidence of potato brown rot, the disease specifically caused by $R$. solanacearum biovar 2 , race $3(23,28)$, has increased in the EU after the first case reported in Sweden in 1976 (47). Since then, outbreaks have been more frequent in the last decade $(15,25$, $28,49,58,63,65)$, with most foci being related to crops irrigated with water contaminated by the pathogen.

The host range of $R$. solanacearum (biovar 2, race 3 ) is not limited to solanaceous plants since it can potentially infect many ornamental and weed species $(29,52,59,63)$. In geranium, $R$. solanacearum was detected in the United States for the first time in 1979 (55). Since 1999 up to the present, $R$. solanacearum biovar 2, race 3 has been isolated from geraniums growing in different greenhouses in both the United States and Canada (3$5,22,26,64)$. The imported plants came from Guatemala, Costa Rica, Mexico, or Kenya. In Europe, geranium samples infected with $R$. solanacearum biovar 2, race 3 were detected in 1999 and 2000 in the United Kingdom, Belgium, Germany, and The Netherlands, and the origin of infections was traced to cuttings from Kenya (29). Because latent infections in other host plants are considered to play a role in the spread of bacterial wilt within and between countries (23), the latent or symptomatic presence of

Corresponding author: M. M. Lopez; E-mail address: mlopez@ivia.es

doi:10.1094/PHYTO-98-8-0949

(c) 2008 The American Phytopathological Society
$R$. solanacearum in geranium raises concern that the bacterium could move from ornamental plants into other hosts, soil, or irrigation water. Since there is an overwhelming volume of imported geranium cuttings, the interest in developing sensitive, reliable, and accurate detection and diagnostics methods of $R$. solanacearum from this plant material is increasing, but the fact this pathogen can latently infect geraniums (57) makes it difficult to detect.

Although isolation of this quarantine organism is usually required in detection protocols, as stated in the EU Directive 98/57/EC (2), culture-independent molecular techniques can be used as a screening method to circumvent the problems associated with the possible presence of stressed, injured, or viable but nonculturable (VBNC) cells. Cells in such states are those that progressively lose the ability to form colonies on solid media yet remaining viable, as a possible survival strategy under adverse environmental conditions. Related to the VBNC state, the induction factors can be variable depending on the bacterial species (43), and low temperatures have been demonstrated as responsible for the entry of $R$. solanacearum cells in the VBNC state in water $(6,11,60)$.

Among culture-independent methods, several polymerase chain reaction (PCR) protocols and oligonucleotides have been described for $R$. solanacearum $(7,14,17,48,50,51,53,62)$. Furthermore, an innovative and sensitive co-operational-PCR (Co-PCR) has recently been described (9), which has proven useful for detecting the target from environmental water samples. Co-PCR detection levels were as sensitive as the nested-PCR technique, with the advantage that this method does not require two different annealing temperatures (46). Furthermore, there is increasing interest in combining different techniques in integrated approaches for detection in order to avoid false negatives as well as false positives results $(1,36)$. In this context, we have developed and evaluated an integrated protocol, combining several techniques, 
for specific and sensitive detection of $R$. solanacearum in asymptomatic geranium cuttings.

\section{MATERIALS AND METHODS}

Bacterial strains and growth conditions. $R$. solanacearum biovar 2 strains PD 2762, IVIA 2833-6.2, and UW551 were used in this study. Strain PD 2762 was isolated from potato (Solanum tuberosum) in The Netherlands and strain IVIA 2833-6.2 from geranium cuttings imported to Spain in 2003. Strain UW551 was also isolated in 2003 from a wilted geranium plant (Pelargonium hortorum) growing in a Wisconsin greenhouse, but from cuttings produced in Kenya. Strains were routinely grown on modified yeast extract-peptone-glucose agar (YPGA) medium (34) with filter sterilized glucose, at $29^{\circ} \mathrm{C}$ for $72 \mathrm{~h}$ and maintained at $-80^{\circ} \mathrm{C}$ with $30 \%$ glycerol.

Plant material. Tomato plants (Lycopersicon esculentum 'Roma') at the third true-leaf stage were used for bioassays and pathogenicity tests as previously described (2). Two-month-old geranium plants (Pelargonium $\times$ hortorum and $P$. peltatum) from a nursery in Valencia (Spain), with no previous history of $R$. solanacearum infection, were used for the protocol standardization. For protocol evaluation, samples of asymptomatic geranium cuttings of cultivars imported to Spain from Kenya in 2003 and 2004 were analyzed.

Spiked geranium samples preparation. In order to simulate latent $R$. solanacearum infections, basal stem parts from healthy geraniums were incubated in $4.5 \mathrm{ml}$ of phosphate-buffered saline (PBS) for $2 \mathrm{~h}$ with shaking, as described later for sampling. Then, extracts were inoculated with a bacterial suspension of the strain IVIA 2833-6.2 at serial decimal decreasing doses (from $10^{8}$ to 1 colony forming units $[\mathrm{CFU}] / \mathrm{ml}$ ) prepared from a culture growing in YPGA for $72 \mathrm{~h}$. The protocols for testing these spiked samples were the same as for naturally infected ones, described later.

Analysis of imported asymptomatic geranium cuttings. Portions of vascular tissue from geranium cuttings of about $0.5 \times$ $0.5 \mathrm{~cm}$ from the lowest part of the stems were aseptically comminuted in $4.5 \mathrm{ml}$ of PBS and incubated for about $2 \mathrm{~h}$ at room temperature with shaking. The extracts were individually processed by isolation on modified YPGA (34) and modified semiselective agar (SMSA) medium (14), indirect immunofluorescence (IIF), double-antibody-sandwich indirect enzymelinked immunosorbent assay (DASI-ELISA) and Co-PCR. For isolation, $0.1 \mathrm{ml}$ of the extracts were used by spreading; $0.1 \mathrm{ml}$ from the enrichment culture were used for DASI-ELISA; $30 \mu \mathrm{l}$ for immunofluorescence; $0.2 \mathrm{ml}$ for DNA extraction, and $5 \mu \mathrm{l}$ of the undiluted or 10-fold diluted after DNA extraction were used as sample for PCR amplifications. In these two last cases, because of the small sample sizes, several aliquots were processed. All the analyses were performed, at least twice, in separate experiments. Aliquots of $0.5 \mathrm{ml}$ of the extracts were conserved at $-80^{\circ} \mathrm{C}$ with $30 \%$ glycerol for further inoculation in tomato plants.

Isolation, enrichment, and identification of $R$. solanacearum. $R$. solanacearum-like colonies were observed and counted, after incubation on SMSA for $48 \mathrm{~h}$ to 5 days at $29^{\circ} \mathrm{C}$. Presumptive $R$. solanacearum colonies were purified on YPGA and confirmed by IIF, DASI-ELISA, and Co-PCR before biovar determination (19). During the direct isolation process, part of the sample $(0.5 \mathrm{ml})$ was used for enrichment by mixing with $4.5-\mathrm{ml}$ of semiselective modified-Wilbrink broth (MWB) according to Caruso et al. (10) in order to improve $R$. solanacearum detection. Geranium extracts in MWB were incubated at $29^{\circ} \mathrm{C}$ for 48 to $72 \mathrm{~h}$ with gentle shaking $(125 \mathrm{rpm})$ in a Lab-line orbital shaker model 4628. Enriched samples were plated on modified YPGA and modified SMSA agar and also processed by DASI-ELISA and Co-PCR. All analyses were performed at least twice, in separate experiments.
IIF. Antiserum 1546-H IVIA obtained against a Spanish $R$. solanacearum biovar 2 strain was used for IIF according to Caruso et al. (10), to confirm that isolated colonies were $R$. solanacearum and to detect the pathogen in geranium extracts directly. Only a staining similar to that exhibited by the homologous strain (positive control) was scored as positive. Filter sterilized PBS was used as negative control.

DASI-ELISA. DASI-ELISA was basically performed as described by Caruso et al. (10) using the detection kit supplied by Plant Print Diagnostics (Valencia, Spain), which includes the specific monoclonal antibody 8B-IVIA. This technique was used to analyze spiked and nonspiked geranium samples at least in duplicate, in separate assays. Strain PD 2762, used to raise the MAb, was employed as a positive control, whereas strain P 27 of Chryseobacterium indologenes was the negative one. Values of optical density (OD) at $450 \mathrm{~nm}$ that were over twice those of the negative control were considered positive.

DNA extraction. DNA was isolated from geranium plant extracts $(200 \mu \mathrm{l})$ using the DNeasy Plant Mini Kit (Qiagen) according to the manufacturer's protocol, eluted with $50 \mu \mathrm{l}$ of DNase-free water, and stored at $-20^{\circ} \mathrm{C}$. DNA extractions were used directly or $1 / 10$ diluted in sterile water to dilute potential polymerase inhibitors.

Conventional PCR and Co-PCR. Conventional PCR was performed according to Caruso et al. (9) using OLI1 (14,53) and $\mathrm{Z}$ (7) primers, for amplification of a 403-bp fragment. The reaction was performed in a final volume of $25 \mu \mathrm{l}$ with the following reagents: $10 \times \mathrm{Taq}$ buffer, $2.5 \mathrm{mM} \mathrm{MgCl}_{2}, 0.1 \mathrm{mM}$ concentrations of each deoxynucleoside triphosphate, $0.1 \mu \mathrm{M}$ of each primer, $1 \mathrm{U}$ of Taq DNA polymerase and $5 \mu \mathrm{l}$ of sample. Amplification conditions included a denaturation step at $94^{\circ} \mathrm{C}$ for $5 \mathrm{~min}$, followed by 40 cycles at $94^{\circ} \mathrm{C}$ for $30 \mathrm{~s}, 60^{\circ} \mathrm{C}$ for $30 \mathrm{~s}$, and $72^{\circ} \mathrm{C}$ for $1 \mathrm{~min}$ and then one cycle of $72^{\circ} \mathrm{C}$ for $10 \mathrm{~min}$ in a MasterCycler Gradient (Eppendorf) thermal cycler. Co-PCR was carried out following the methodology also described by Caruso et al. (9), with OLI1, OLI2 (14), and JE-2 (14). The reaction was performed in a final volume of $25 \mu \mathrm{l}$ with $10 \times$ Taq buffer, $4 \mathrm{mM}$ $\mathrm{MgCl}_{2}, 0.2 \mathrm{mM}$ concentrations of each deoxynucleoside triphosphate, $5 \%$ dimethyl sulfoxide (DMSO), 3\% formamide, $0.15 \mu \mathrm{M}$ OLI1 and OLI 2 primers, $0.075 \mu \mathrm{M}$ JE-2 primer, $1 \mathrm{U}$ of Taq DNA polymerase (GIBCO-BRL), and $5 \mu$ of sample. The amplification was performed by a denaturation phase at $95^{\circ} \mathrm{C}$ for $3 \mathrm{~min}$, followed by 55 cycles at $94^{\circ} \mathrm{C}$ for $30 \mathrm{~s}, 65^{\circ} \mathrm{C}$ for $30 \mathrm{~s}$, and $72^{\circ} \mathrm{C}$ for $45 \mathrm{~s}$, and then one cycle of $72^{\circ} \mathrm{C}$ for $10 \mathrm{~min}$ in a MasterCycler Gradient (Eppendorf) thermal cycler. Both conventional and CoPCR were used to detect $R$. solanacearum in geranium extracts, both directly and after enrichment, and to confirm the identfication of suspected colonies grown on solid media. Positive and negative controls were the strain PD 2762 and sterile PBS, respectively. Amplified products were separated by electrophoresis $(100 \mathrm{~V})$ on $2 \%$ agarose gels.

Biochemical tests. The biochemical tests used for the presumptive $R$. solanacearum colonies were: oxidative metabolism of glucose through $\mathrm{O} / \mathrm{F}$ medium, oxidase activity, use of Simmons citrate, and hydrolysis of esculin. Biovar determination was also performed, based on using cellobiose, lactose and maltose, and oxidation of the hexose alcohols dulcitol, mannitol, and sorbitol (19), and the methodology used was that described in the EU Directive as official protocol (2). Positive and negative controls were the same as for the Co-PCR.

Bioassays and pathogenicity tests. Bioassays were performed according to the EU Directive (2). Briefly, $10 \mu \mathrm{l}$ of the geranium extracts was inoculated into tomato stems between the cotyledons (27). Plants were maintained at $28^{\circ} \mathrm{C} 16 \mathrm{~h}$ light $/ 8 \mathrm{~h}$ dark and high relative humidity for 28 days, assessed daily for wilt symptoms, and sampled to recover the pathogen by isolation. Stem pieces approximately $0.5 \mathrm{~cm}^{3}$ from the inoculation site and $5 \mathrm{~cm}$ above and below that site were comminuted in saline solution and the 
extract spread on LPGA and SMSA media. Furthermore, to confirm the pathogenicity of strains identified as $R$. solanacearum, virulence assays were performed both in tomato and geranium by stem inoculation, as described previously, with suspensions of suspected colonies at $10^{6}$ to $10^{8} \mathrm{CFU} / \mathrm{ml}$. Ten plants were inoculated for each strain. The negative control was the same as for the Co-PCR, and strain UW551 was used as positive control for comparative purposes.

\section{RESULTS}

Sensitivity assessment of the different detection techniques. Spiked geranium extracts, inoculated with serial 10-fold dilutions of $R$. solanacearum suspensions, were analyzed by isolation (on general and semiselective media), serological (IIF and DASIELISA), and molecular techniques (conventional and Co-PCR), with or without previous enrichment in liquid medium. Moreover, a tomato bioassay was included to potentially multiply bacteria from samples with very low numbers of the pathogen. Results from all these analyses are shown in Table 1. The detection limit was about $10^{3} \mathrm{CFU} / \mathrm{ml}$ for both YPGA and SMSA plate counts and $10^{2} \mathrm{CFU} / \mathrm{ml}$ after enrichment; $10^{4}$ cells $/ \mathrm{ml}$ for conventional $\mathrm{PCR}$, and 1 cell $/ \mathrm{ml}$ for Co-PCR. PCR amplifications were sometimes inhibited in geranium extracts as observed by processing at the same time the DNA extracts and their dilutions, but they always worked when samples were serially (10-fold) diluted (Fig. 1). DASI-ELISA and IIF were positive for all dilutions, with strong background fluorescence observed in all samples stained by IIF, regardless of the dilution considered and also after the enrichment step. In DASI-ELISA most of the wells in the plates also provided very high OD values, even in some negative controls with only healthy geranium extracts. Regarding pathogenicity, the dilutions of $R$. solanacearum in spiked geranium extracts with $10^{4} \mathrm{CFU} / \mathrm{ml}$ or higher concentrations caused the typical wilting symptoms in inoculated tomatoes after 7 days, leading to the death of nearly $100 \%$ of the tomatoes after 2 to 3 weeks of

TABLE 1. Sensitivity of different techniques for Ralstonia solanacearum detection in spiked geranium extract

\begin{tabular}{llc}
\hline & \multicolumn{2}{c}{ Sensitivity } \\
\cline { 2 - 3 } Techniques & Before enrichment & After enrichment \\
\hline${\text { Plate count on } \text { YPGA }^{\mathrm{b}}}_{\text {Plate count on SMSA }^{\mathrm{b}}}$ & $3 \times 10^{3} \mathrm{CFU} / \mathrm{ml}$ & $10^{2} \mathrm{CFU} / \mathrm{ml}$ \\
Co-PCR $^{\mathrm{c}}$ & $1.5 \times 10^{3} \mathrm{CFU} / \mathrm{ml}$ & $10^{2} \mathrm{CFU} / \mathrm{ml}$ \\
PCR $^{\mathrm{d}}$ & $1 \mathrm{cell} / \mathrm{ml}$ & $1 \mathrm{cell} / \mathrm{ml}$ \\
DASI-ELISA $^{\mathrm{e}}$ & $\mathrm{ND}$ & $10^{3} \mathrm{cellls} / \mathrm{ml}$ \\
IIF $^{\mathrm{f}}$ & $\mathrm{ND}$ & $1 \mathrm{CFU} / \mathrm{ml}$ \\
Pathogenicity $^{\mathrm{g}}$ & $10^{4} \mathrm{CFU} / \mathrm{ml}$ & $\mathrm{ND}$ \\
\hline
\end{tabular}

a Enrichment performed in modified-Wilbrink broth, according to Caruso et al. (10).

${ }^{b}$ Plate counts were determined, directly from the plant extract or after enrichment, on the nonselective medium yeast extract-peptone-glucose agar (YPGA) (34) and the semiselective agar SMSA (14).

c Co-operational-polymerase chain reaction (Co-PCR) carried out after DNA extraction, according to Caruso et al. (9), using OLI1 (14,53), OLI2 (14), and JE-2 (14) primers.

${ }^{\mathrm{d}}$ Conventional PCR performed with OLI1 and Z (7) primers, according to Caruso et al. (9).

e Double-antibody-sandwich indirect enzyme-linked immunosorbent assay (DASI-ELISA) basically performed as described by Caruso et al. (10) using the detection kit supplied by Plant Print Diagnostics (Valencia, Spain), which includes the specific monoclonal antibody 8B-IVIA. (Performed only after enrichment because the sensitivity of this technique before enrichment is very low.)

${ }^{\mathrm{f}}$ Indirect immunofluorescence (IIF), with the antiserum 1546-H IVIA obtained against a Spanish $R$. solanacearum biovar 2 strain according to Caruso et al. (10): results not included because of the high background fluorescence in all samples.

g Pathogenicity assays made in tomato plants by inoculation of $10 \mu \mathrm{l}$ of geranium extract into stem between the cotyledons (27). inoculation; however, extracts with bacterial cell counts ranging from $10^{2}$ to $10^{0} \mathrm{CFU} / \mathrm{ml}$ did not produce visible symptoms in all the inoculated plants, and the bacterium was not always reisolated from them.

Protocol for detecting $\boldsymbol{R}$. solanacearum in asymptomatic geranium cuttings. Based on the results described previously, a protocol was developed to detect $R$. solanacearum in asymptomatic geranium cuttings (Fig. 2), for which isolation and Co-PCR were proposed as the two basic tools to analyze asymptomatic cuttings. According to this protocol, bioassays would be performed when isolation was negative and Co-PCR was positive; then, $R$. solanacearum-like colonies recovered from inoculated tomatoes would be subjected to identification and pathogenicity tests to confirm pathogen detection.

Evaluation of protocol for detection of $\boldsymbol{R}$. solanacearum. A total of 107 samples of asymptomatic geranium cuttings (Pelargonium spp.), imported from Kenya in 2003 and 2004, were analyzed according to the previously designed protocol. The direct isolations were all negative because the colonies on general or semiselective media, before and after enrichment, did not exhibit the typical characteristics of $R$. solanacearum or were not identified as this pathogen. However, 23 samples tested positive by DASI-ELISA after enrichment. Results from IIF were confusing because high background fluorescence was observed in all samples, which masked detection of target cells. With respect to the Co-PCR, though no amplification was obtained from the direct geranium DNA extractions, the specific band of 408 bp was clearly amplified in 30 samples when these extractions were diluted 10-fold. Ten samples that were negative for isolation and positive for Co-PCR were randomly selected and extracts inoculated in tomato stems. Plants did not show evident symptoms of bacterial wilt, but typical $R$. solanacearum fluid colonies were reisolated after 7 days and their identity as $R$. solanacearum biovar 2 confirmed by biochemical, serological, and molecular tests. Results for positive and negative controls were as expected.

$\boldsymbol{R}$. solanacearum inoculated in tomato and geranium plants. All tomatoes inoculated with the strains recovered from bioassayed tomatoes showed the typical wilt symptoms after 7 days.

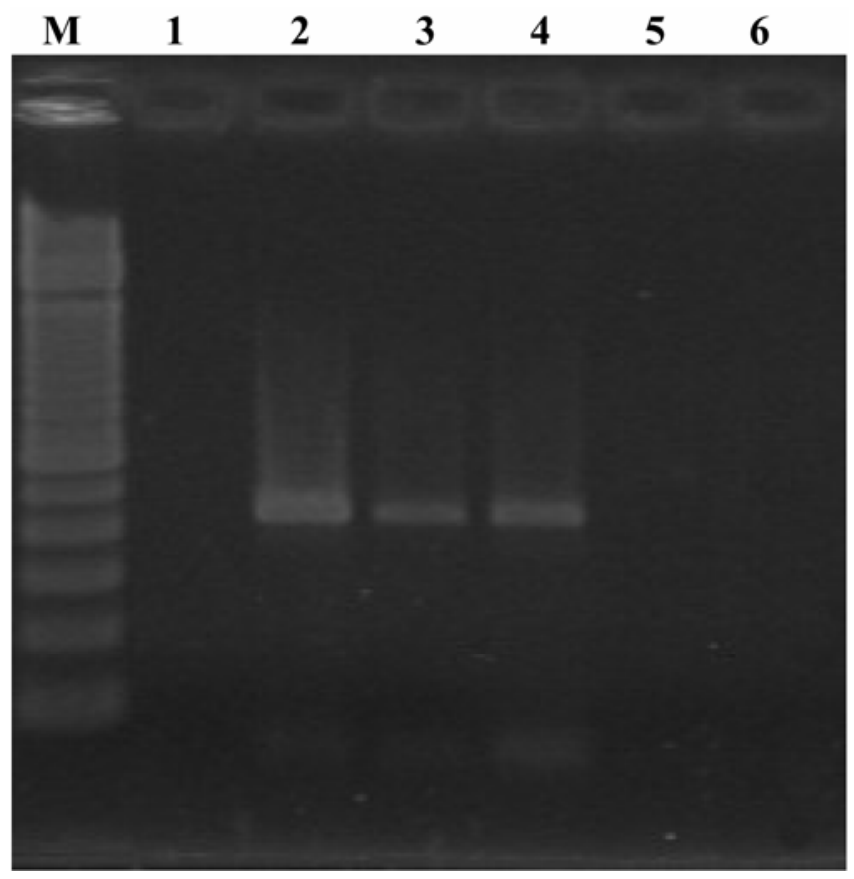

Fig. 1. Amplification by co-operational polymerase chain reaction using DNA extracted from geranium cutting samples. M, Molecular marker; 1 , undiluted $R$. solanacearum spiked geranium extract sample; 2 to 5,10 -fold serial diluted samples $\left(10^{2}, 10^{1}, 10^{0}\right.$, and $\left.10^{-1} \mathrm{CFU} / \mathrm{ml}\right)$; and 6 , negative control. 
However, most geraniums inoculated with the same strains showed only minor symptoms, such as some wilted leaves and other leaves with V-shaped spots (Fig. 3), at 20 days postinoculation. Nevertheless, $R$. solanacearum was recovered from both wilted and asymptomatic plants. At the same postinoculation time, strain UW551, used as positive control, caused wilting in almost $40 \%$ of the plants, and the pathogen was re-isolated. All colonies were confirmed as $R$. solanacearum by IIF and Co-PCR.

\section{DISCUSSION}

The ability of $R$. solanacearum biovar 2, race 3, to produce latent infections in geranium plants is well known (57) and can lead to false negative results when analyzing asymptomatic cuttings only by isolation. Therefore, the threat of potential introduction of this pathogen in asymptomatic geranium cuttings is real and should not be underestimated. In an effort to minimize the risk of introducing this bacterium through asymptomatic plant material, we have developed a rapid and sensitive protocol to detect $R$. solanacearum in geranium cuttings. Moreover, this is the first report to deal with the detection of this quarantine organism in imported geraniums in Spain.

The analyses of geranium cuttings for $R$. solanacearum according to the EU Directive 98/57/EC (2) by cultural, serological, and

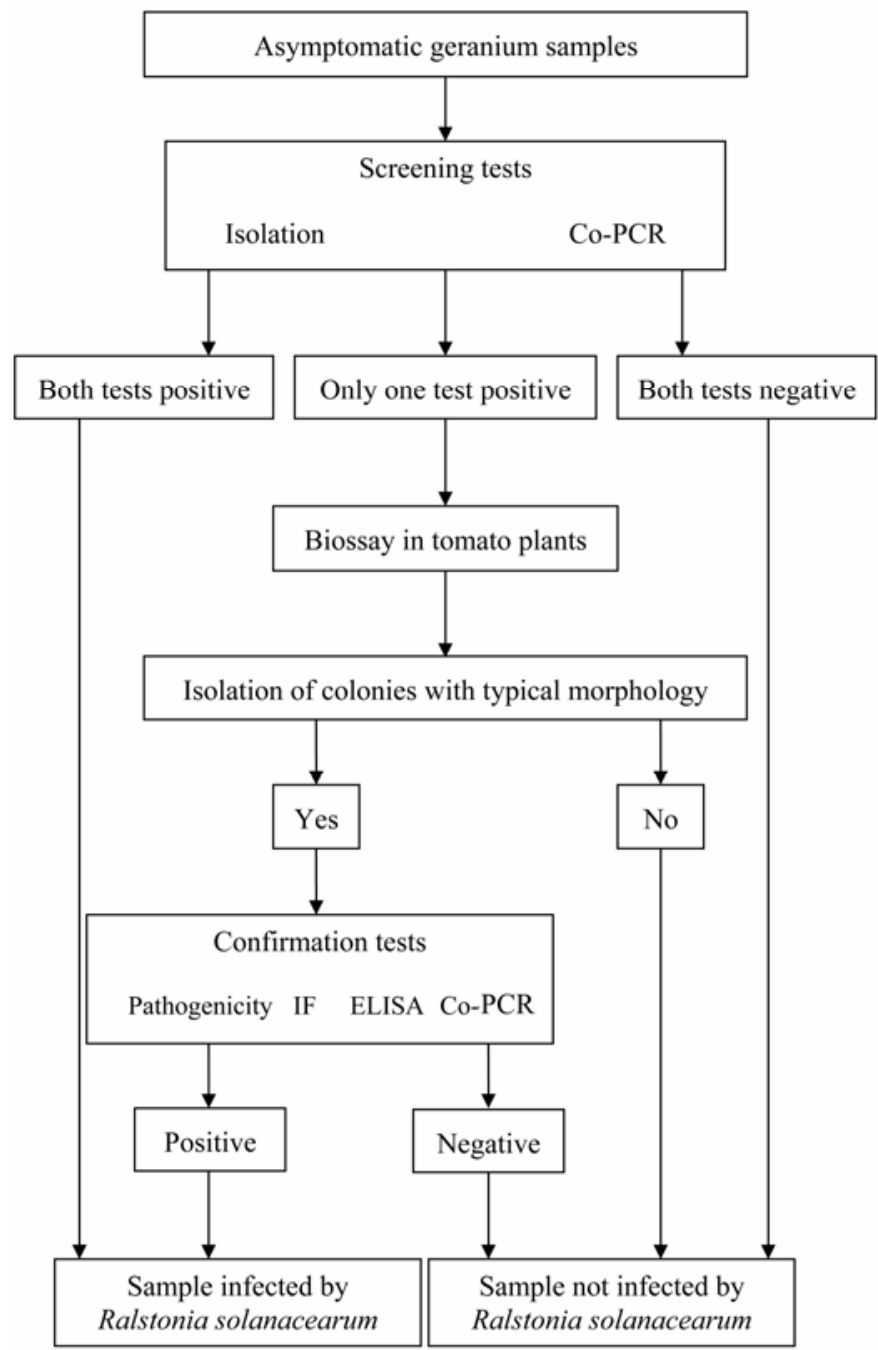

Fig. 2. Flow chart diagram of the proposed protocol to detect Ralstonia solanacearum in asymptomatic geranium plants. Co-PCR indicates co-operational-polymerase chain reaction according to Caruso et al. (9). IF indicates indirect immunofluorescence with $R$. solanacearum-specific antibodies. ELISA indicates ELISA with $R$. solanacearum-specific monoclonal antibodies. molecular methods require the isolation of the bacterium on solid media to confirm its detection. In our samples, a discrepancy between cultural and molecular methods was revealed, since no colonies of $R$. solanacearum were recovered, whereas positive detection was obtained by Co-PCR. To assess the sensitivity of the different detection techniques employed, we inoculated geranium extracts with decreasing dilutions of the pathogen, and then compared the detection efficiency of cultural and molecular techniques in these spiked samples. The Co-PCR technique displayed the highest sensitivity, being able to detect $1 \mathrm{cell} / \mathrm{ml}$ of plant extract. The high sensitivity of this PCR protocol in comparison to other methods was previously reported in the detection of the target bacteria in environmental waters (9). Sensitivity by isolation was around $10^{3} \mathrm{CFU} / \mathrm{ml}$, and it improved detection to $10^{2} \mathrm{CFU} / \mathrm{ml}$ when an enrichment step was performed prior to isolation. However, these CFU numbers may overestimate the efficiency of isolation under natural conditions, since in nature the pathogen must compete with other microbes which can overgrow target organism on the culture media, thus masking detection of $R$. solanacearum.

Furthermore, target bacterial cells in the sample could be present at very low levels or in a particular physiological state, such as injured (38) or VBNC (42), thus escaping detection by cultural methods. Injured cells are not detected on selective solid media but they can grow on general ones; cells in the VBNC state are even unable to grow on general solid media but remain viable as measured by culture independent methods. Both injured and VBNC cells can be induced by several environmental factors. In fact, the VBNC state has been demonstrated in $R$. solanacearum at low temperatures $(6,11,60,61)$. Therefore, detection of $R$. solanacearum based mainly on culturability could lead to an underestimation of its presence. In contrast, Co-PCR, which is a more sensitive technique, detects injured and VBNC cells, and is not affected by the growth of competitors as it does not need an enrichment step, something that also contributes to the speed of analysis. The only caution to consider in PCR analysis is to dilute the samples to minimize the effect of inhibitors, a common problem in PCR detection of plant pathogens in crude plant extracts $(31,37,39,56)$, which has already been reported in geranium tissue $(21,51)$. Dilutions in the range of $1 / 100$ to $1 / 500$, which involve a drastic reduction in sensitivity, have been reported as successful for Pelargonium asperum (51) with no DNA extraction; by contrast, in present work, 10-fold dilutions of DNA extractions were enough to give a strong target signal by Co-PCR, as previously described for certain water samples with the same protocol (9), allowing positive results with the pathogen at low levels even in the presence of high numbers of indigenous microbiota (up to $10^{5} \mathrm{CFU} / \mathrm{ml}$ ). Thereafter, it has been successfully applied to potato plant material (unpublished data) and in this study to geranium. In spiked geranium extracts, Co-PCR was much more sensitive than conventional PCR, and therefore the former was chosen as a screening method. In fact, it has been stated that the detection threshold of single round PCR is not sensitive enough to detect early or latent infections of $R$. solanacearum (51). However, Co-PCR has several advantages over other developed PCR protocols, such as high sensitivity and reduced risk of cross-contamination, because all reactions occur in just one tube. Indeed, such a technique has been considered as appropriate for routine use, due to its good specificity and sensitivity (9).

Serological methods, such as IIF and ELISA, were of limited interest because the assayed geranium extracts caused a strong background fluorescence that hampered the visualization of target cells by IIF or gave positive result in most wells of ELISA plates. Furthermore, the background was observed in geranium extracts even after dilution in water (IIF) or dilution in modified Wilbrink broth used for enrichment (DASI-ELISA), and true positive results obtained by IIF and ELISA could not be distinguished from false positive ones. 
Regarding bioassays, these were performed with geranium extracts containing $R$. solanacearum cells in the range of $10^{8}$ to $10^{0} \mathrm{CFU} / \mathrm{ml}$. The analysis of the inoculated plants provided positive results by Co-PCR in all of them, but only positive by isolation at concentrations higher than $10^{3} \mathrm{CFU} / \mathrm{ml}$. The inoculation of extracts with $10^{2} \mathrm{CFU} / \mathrm{ml}$ in tomatoes produced the typical bacterial wilt symptoms in only some plants, and $R$. solanacearum was reisolated from them. In this respect, Swanson et al. (57), assaying soil-soak inoculations, observed that $20 \%$ of geranium plants were latently infected, with the proportion of plants developing active infections varying greatly between experiments. Obviously, the inclusion of a larger number of bioassayed plantlets ( 25 to 50 per extract instead of 10 plantlets) could increase the reliability of the protocol. A large proportion of sites in latently infected plants has even been reported to contain zero or no detectable $R$. solanacearum cells because of the uneven distribution of bacterial cells (57). This fact indicates that random stem sampling can be an unreliable testing method. $R$. solanacearum evaluated strains seem not to reveal a particularly aggressive pathogen for some geranium cultivars $(41,57)$, and their ability to cause latent infections can generate plants with inoculum that led to the disease spreading only after variable periods of time under favourable conditions (57).

We have demonstrated that the lack of accordance between isolation and molecular results could mask the presence of this pathogen and subsequently play down the real danger of introducing the bacterium on asymptomatic plants. Based on the results of spiked geranium extracts, we have designed a protocol to analyze asymptomatic geraniums for the presence of $R$. solanacearum when this pathogen is present in low numbers, and/or in particular physiological states and/or in latent infections.

The protocol was evaluated with geranium cuttings imported from Kenya, where $R$. solanacearum biovar 2 had been detected in watercourses as reported by Janse et al. (29). In our study, from a total of 107 samples, no $R$. solanacearum cell was isolated directly from the cuttings, even after enrichment. However, in 30 samples the pathogen was detected by Co-PCR. According to our protocol, some of the samples testing positive by Co-PCR and negative by isolation were analyzed by bioassay, and $R$. solanacearum was reisolated from tomatoes developing typical bacterial wilt symptoms. When these strains were tested in geranium plants, they developed latent infections producing only minor symptoms, and again $R$. solanacearum was re-isolated from most challenged plants. Variability in susceptibility of geranium cultivars to $R$. solanacearum and in the pathogen variation to produce symptoms has been reported (41). Our results demonstrated the usefulness of the protocol, because target cells (alive, injured, VBNC, or even in low numbers) can be detected by Co-PCR. Moreover, these cells, although not recovered by direct isolation, can be recovered in a second isolation step from tomato plants inoculated with the geranium extracts.

$R$. solanacearum cells can be released from the roots of infected geraniums during cultivation, and the ebb-and-flow subirrigation systems are very effective means of disseminating the pathogen (57). A common practice for routine treatment of contaminated irrigation water involves clarification by filtration, then UV radiation, and addition of chlorine dioxide. The presence of particles in water, even the very small particle sizes, has been reported to influence the efficacy of disinfection with UV radiation and chlorine dioxide $(12,30,35,40,54,66)$. This is because pathogens associated with the particles can escape from full exposure to chlorine (20) or UV radiation $(12,16,30)$; moreover, they can form biofilms which can be more resistant to disinfection than unattached cells (18). Furthermore, it has been demonstrated that both UV radiation and treatment with chlorine can induce the VBNC state in several bacteria $(42,43,44,45,68)$ or reversible cell injury (38). Following such water treatments, three populations of the target cells could probably be distinguished: a majority of dead cells, a few culturable cells, and a large population of injured or VBNC cells, as reported for E. coli after chlorination
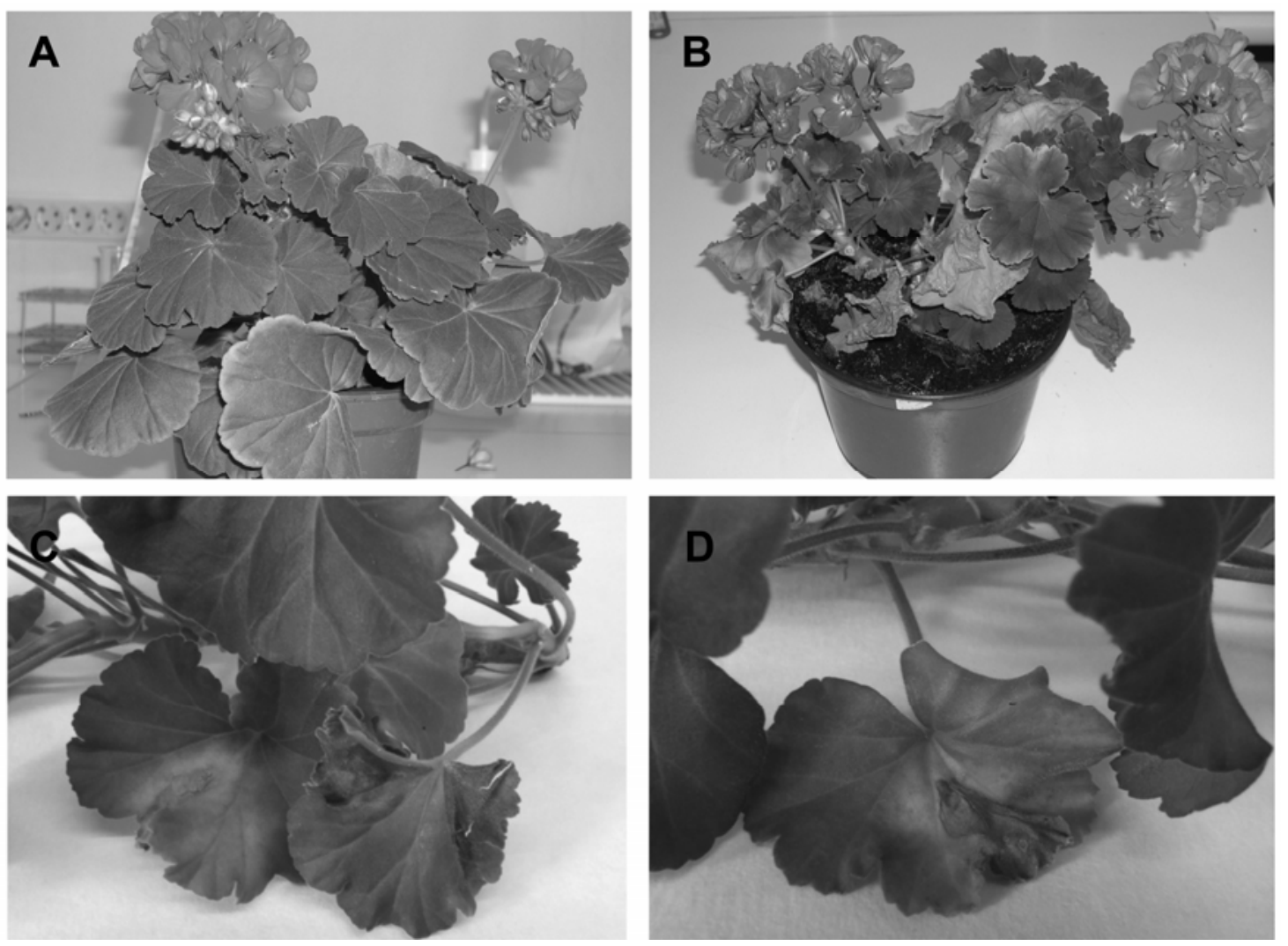

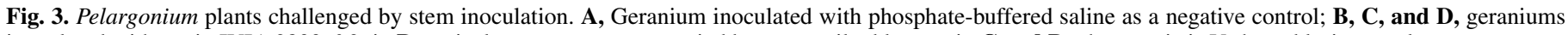
inoculated with strain IVIA 2833-6.2; in B, typical symptoms accompanied by some wilted leaves; in C and D, characteristic V-shaped lesions on leaves. 
$(13,33)$. Thus, the particular physiological states that $R$. solanacearum can adopt under these conditions (that have not been studied yet) necessitates the use of detection techniques complementary to isolation, able to detect nonculturable or injured bacterial cells. In our survey, $R$. solanacearum cells that were not recovered by isolation but detected by Co-PCR were probably in a stressed state, potentially reversible by passage through a host plant.

In the developed protocol, both isolation and Co-PCR are proposed as basic tools for testing plant material. Isolation on SMSA medium, directly from extracts or after bioassay in tomato plants, was selected because it provides information about the active physiological state of the bacterium, which could divide and proliferate in the plant and, also, because it is the main test outlined by the EU Directive for detection of $R$. solanacearum in potato. The Co-PCR technique was chosen because of its sensitivity, specificity, speed, and ease of use (9) as explained above.

In conclusion, improved detection methods are needed given the fact that $R$. solanacearum could possibly spread from ornamental plants (originally grown in tropical or subtropical areas) to susceptible hosts in European or other countries. This improved detection can be achieved through a combination of different techniques, such as those outlined in the protocol developed as result of this study. Therefore, such protocols should be considered for the analysis of asymptomatic cuttings in the implementation of preventive measures to reduce the likelihood for introduction of geranium bacterial wilt to new areas.

\section{ACKNOWLEDGMENTS}

This work was supported through projects GV-04B313 and GV05/214 from Generalitat Valenciana and the agreement between the Ministerio de Agricultura y Pesca of Spain (Subdirección General de Agricultura Integrada y Sanidad Vegetal) and Instituto Valenciano de Investigaciones Agrarias. E. Marco-Noales had a contract from the Ministerio de Educación y Ciencia (MEC) (Programa INIA/CC.AA), Spain; afterwards, a contract from Agroalimed Foundation (Generalitat Valenciana) and now a new contract from the MEC (Programa INIA/CC.AA) co-funded by the European Social Fund (ESF). E. Bertolini was recipient of a fellowship grant (CTBPDC/2004/034) from Consellería de Cultura, Educación y Deporte of the Generalidad Valenciana and now a Juan de la Cierva contract from MEC. We thank C. Allen and J. Janse for kindly sending $R$. solanacearum strains UW551 and PD 2762, respectively. English text revised by F. Barraclough.

\section{LITERATURE CITED}

1. Álvarez, A. M. 2004. Integrated approaches for detection of plant pathogenic bacteria and diagnosis of bacterial diseases. Annu. Rev. Phytopathol. 42:339-366.

2. Anonymous. 1998. Council Directive 98/57/EC of 20 July 1998 on the control of Ralstonia solanacearum (Smith) Yabuuchi et al. Off. J. Eur. Communities L235/1:21.08.98.

3. Anonymous. 2003. Ralstonia solanacearum, race 3 (Biovar2) intercepted on imported Pelargonium spp.: Trace back, survey and regulatory action. Phytosanitary Alert System of North American Plant Protection Organization (NAPPO).

4. Anonymous. 2004. Ralstonia solanacearum race 3 biovar 2 in a Florida Nursery. Official Pest Reports. National Plant Protection Organization.

5. APHIS-PPQ. 2004. USDA-APHIS pest alert: Ralstonia solanacearum race 3 biovar 2 Southern wilt of geranium. Published online by USDAAPHIS PPQ Pest Detection and Management Programs.

6. Biosca, E. G., Caruso, P., Bertolini, E., Álvarez, B., Palomo, J. L., Gorris, M. T., and López, M. M. 2005. Improved detection of Ralstonia solanacearum in culturable and VBNC state from water samples at low temperatures. Pages 501-506 in: Bacterial Wilt Disease and the Ralstonia solanacearum Species Complex. C. Allen, P. Prior, and C. Hayward, eds. American Phytopathological Society, St. Paul, MN.

7. Boudazin, G., Le Roux, A. C., Josi, K., Labarre, P., and Jouan, B. 1999. Design of division specific primers of Ralstonia solanacearum and application to the identification of European isolates. Eur. J. Plant Pathol. 105:373-380.
8. Bradbury, J. F. 1986. Guide to Plant Pathogenic Bacteria. CAB International, Wallingford, UK.

9. Caruso, P., Bertolini, E., Cambra, M., and López, M. M. 2003. A new and sensitive co-operational polymerase chain reaction (Co-PCR) for a rapid detection of Ralstonia solanacearum in water. J. Microbiol. Methods 55:257-272.

10. Caruso, P., Gorris, M. T., Cambra, M., Palomo, J. L., Collar, J., and López, M. M. 2002. Enrichment double-antibody sandwich indirect enzyme-linked immunosorbent assay that uses a specific monoclonal antibody for sensitive detection of Ralstonia solanacearum in asymptomatic potato tubers. Appl. Environ. Microbiol. 68:3634-3638.

11. Caruso, P., Palomo, J. L., Bertolini, E., Álvarez, B., López, M. M., and Biosca, E. G. 2005. Seasonal variation of Ralstonia solanacearum biovar 2 populations in a Spanish river: Recovery of stressed cells at low temperatures. Appl. Environ. Microbiol. 71:140-148.

12. Christensen, J., and Linden, K. G. 2003. How particles affect UV light in the UV disinfection of unfiltered drinking water. J. Am. Water Works Assoc. 95:179-189.

13. Dukan, S., Levi, Y., and Touati, D. 1997. Recovery of culturability of an HOCl-stressed population of Escherichia coli after incubation in phosphate buffer: Resuscitation or regrowth. Appl. Environ. Microbiol. 63:4204-4209.

14. Elphinstone, J. G., Hennessey, J., Wilson, J. K., and Stead, D. E. 1996. Sensitivity of different methods for the detection of Ralstonia solanacearum in potato tuber extracts. EPPO Bull. 26:663-678.

15. Elphinstone, J. G., Stanford, H. M., and Stead, D. E. 1998. Detection of Ralstonia solanacearum in potato tubers, Solanum dulcamara and associated irrigation water extracts. Pages 133-139 in: Bacterial Wilt Disease. Molecular and Ecological Aspects. P. Prior, C. Allen, and J. Elphinstone, eds. Springer-Verlag, Heidelberg, Germany.

16. Emerick, R. W., Loge, F. J., Ginn, T, and Darby, J. L. 2000. Modeling the inactivation of particle-associated coliform bacteria. Water Environ. Res. 72:432-438.

17. Fegan, M., Holoway, G., Hayward, A. C., and Timmis, J. 1998. Development of a diagnostic test based on the polymerase chain reaction (PCR) to identify strains of Ralstonia solanacearum exhibiting the biovar 2 genotype. Pages 34-43 in: Bacterial Wilt Disease. Molecular and Ecological Aspects. P. Prior, C. Allen, and J. Elphinstone, eds. Springer Verlag, Heidelberg, Germany.

18. Ford, T. E. 1993. The microbial ecology of water distribution and outfall systems. Pages 455-482 in: Aquatic Microbiology: An Ecological Approach. T. E. Ford, ed. Blackwell Scientific Publishers, London, UK.

19. French, E. R., Gutarra, L., Alley, P., and Elphinstone, J. 1995. Culture media for Pseudomonas solanacearum isolation, identification and maintenance. Fitopatologia 30:126-130.

20. Gauthier, V., Redercher, S., and Block, J. C. 1999. Chlorine inactivation of Sphingomonas cells attached to goethite particles in drinking water. Appl. Environ. Microbiol. 65:355-357.

21. Glick, D. L., Coffey, C. M., and Sulzinski, M. A. 2002. Simultaneous PCR detection of the two major bacterial pathogens of geranium. J. Phytopathol. 150:54-59.

22. Hamrick, D. 2004. Ralstonia strikes American pelargonium young plants again. FloraCulture International March 14:16-18.

23. Hayward, A. C. 1991. Biology and epidemiology of bacterial wilt caused by Pseudomonas solanacearum. Annu. Rev. Phytopathol. 29:65-87.

24. Hayward, A. C. 1994. The hosts of Pseudomonas solanacearum. Pages 924 in: Bacterial Wilt: The Disease and Its Causative Agent, Pseudomonas solanacearum. A. C. Hayward and G. L. Hartman, eds. CAB International Mycological Institute, Wallingford, UK.

25. Hayward, A. C., Elphinstone, J. G., Caffier, D., Janse, J., Stefani, E., French, E. R., and Wright, A. J. 1998. Round table on bacterial wilt (brown rot) of potato. Pages 420-430 in: Bacterial Wilt Disease. Molecular and Ecological Aspects. P. Prior, C. Allen, and J. Elphinstone, eds. Springer Verlag, Heidelberg, Germany.

26. Hudelson, B. D. 1999. Southern wilt. University of Wisconsin Garden Facts, May 11, 1999.

27. Janse, J. D. 1988. A detection method for Pseudomonas solanacearum in symptomless potato tubers and some data on its sensitivity and specificity. Bull. OEPP 18:343-351.

28. Janse, J. D. 1996. Potato brown rot in western Europe-history, present occurrence and some remarks on possible origin, epidemiology and control strategies. Bull. OEPP 26:679-695.

29. Janse, J. D., van den Beld, H. E., Elphinstone, J., Simpkins, S., Tjou-TamSin, N. N. A., and van Vaerenbergh, J. 2004. Introduction to Europe of Ralstonia solanacearum biovar 2, race 3 in Pelargonium zonale cuttings. J. Plant Pathol. 86:147-155.

30. Jolis, D., Lam, C., and Pitt, P. 2001. Particle effects on ultraviolet disinfection of coliform bacteria in recycled water. Water Environ. Res. 73:233-236.

31. Kirchhof, G., Baldani, J., Reis, V. M., and Hartmann, A. 1998. Molecular 
assay to identify Acetobacter diazotrophicus and detect its occurrence in plant tissues. Can. J. Microbiol. 44:12-19.

32. Lambert, C. D. 2002. Agricultural bioterrorism protection act of 2002: Possession, use, and transfer of biological; agents and toxins; interim and final rule. (7 CFR Part 331). Federal Register 67:76908-76938.

33. LeChevallier, M. W., Welch, N. J., and Smith, D. B. 1999. Full-scale studies of factors related to coliform regrowth in drinking water. Appl. Environ. Microbiol. 62:2201-2211.

34. Lelliot, R. A., and Stead, D. E. 1987. Methods for the diagnosis of bacterial diseases of plants. Page 216 in: Methods in Plant Pathology. vol. 2. T. F. Preece, ed. Blackwell Scientific Publications, Oxford, UK.

35. Loge, F. J., Emerick, R. W., Thompson, D. E., Nelson, D. C., and Darby, J. L. 1999. Factors influencing ultraviolet disinfection performance part I: Light penetration to wastewater particles. Water Environ. Res. 71:377381.

36. López, M. M., Bertolini, E., Olmos, A., Caruso, P., Gorris, M. T., Llop. P., Penyalver, R., and Cambra, M. 2003. Innovative tools for detection of plant pathogenic viruses and bacteria. Int. Microbiol. 6:233-243.

37. Maes, M., Garbeva, P., and Crepel, C. 1996. Identification and sensitive endophytic detection of the fire blight pathogen Erwinia amylovora with 23S ribosomal DNA sequences and the polymerase chain reaction. Plant Pathol. 45:1139-1149.

38. McFeters, G. A., and LeChevallier, M. W. 2000. Chemical disinfection and injury of bacteria in water. Pages 255-275 in: Nonculturable Microorganisms in the Environment. R. R. Colwell and J. D. Grimes eds. American Society for Microbiology Press, Washington, DC

39. Minsavage, G. V., Thompson, C. M., Hopkins, D. L., Leite, R. M. V. B. C., and Stall, R. E. 1994. Development of a polymerase chain reaction protocol for detection of Xylella fastidiosa in plant tissue. Phytopathology 84:456-461.

40. Morin, P., Camper, A., Jones, W., Gatel, D., and Goldman, J. C. 1996. Colonization and disinfection of biofilms hosting coliform-colonized carbon fines. Appl. Environ. Microbiol. 62:4428-4432.

41. Norman, D. J., Yuen, J. M. F., and Mangravita-Novo, A. 2006. Susceptibility of geranium cultivars to bacterial wilt. Page 94 in: Abstr. 4th International Bacterial Wilt Symposium. British Society for Plant Pathology, York, UK.

42. Oliver, J. D. 1993. Formation of viable but nonculturable cells. Pages 239-272 in: Starvation in bacteria. S. Kjelleberg, ed. Plenum Press, New York.

43. Oliver, J. D. 2000a. Public health significance of viable but nonculturable bacteria. In: Non-culturable microorganisms in the environment. R. R. Colwell and D. J. Grimes, eds. American Society for Microbiology Press, Washington, DC.

44. Oliver, J. D. 2000b. Problems in detecting dormant (VBNC) cells, and the role of DNA elements in this response. In: Tracking Genetically Engineered Microorganisms. J. K. Jansson, J. D. van Elsas, and M. Bailey, eds. Landes Bioscience, Georgetown, TX.

45. Oliver, J. D., Dagher, M., and Linden, K. 2005. Induction of Escherichia coli and Salmonella typhimurium into the viable but nonculturable state following chlorination of wastewater. J. Water Health 3:249-257.

46. Olmos, A., Bertolini, E., and Cambra, M. 2002. Simultaneous and Cooperational amplification (Co-PCR): A new concept for detection of plant viruses. J. Virol. Methods 106:51-59.

47. Olson, K. 1976. Experiences on brown rot caused by Pseudomonas solanacearum (Smith) Smith in Sweden. Bull. OEPP 6:199-207.

48. Opina, N., Tavner, F., Holloway, G., Wang, J.-F., Li, T. H., Maghirang, R., Fegan, M., Hayward, A. C., Krishnapillai, V., Hong, W. F., Holloway, B. W., and Timmis, J. N. 1997. A novel method for development of species and strain-specific DNA probes and PCR primers for identifying Burkholderia solanacearum (formerly Pseudomonas solanacearum). Asia-Pac. J. Mol. Biol. 5:19-33.

49. Palomo, J. L., Caruso, P., Gorris, M. T., López, M. M., and GarcíaBenavides, P. 2000. Comparación de métodos de detección de Ralstonia solanacearum en aguas superficiales, Page 120 in: Abstr. 10th Congr. Soc. Española Fitopatol., SEF, Madrid, Spain.

50. Pastrik, K. H., and Maiss, E. 2000. Detection of Ralstonia solanacearum in potato tubers by polymerase chain reaction. J. Phytopathol. 148:619626.
51. Poussier, S., and Luisetti, J. 2000. Specific detection of biovars of Ralstonia solanacearum in plant tissues by nested-PCR-RFLP. Eur. J. Plant Pathol. 106:255-265.

52. Pradhanang, P. M., Elphinstone, J. G., and Fox, R. T. V. 2000. Identification of crop and weed hosts of Ralstonia solanacearum. Plant Pathol. 19:403-413.

53. Seal, S. E., Jakson, L. A., Young, J. P. W., and Daniels, M. J. 1993. Differentiation of Pseudomonas solanacearum, Pseudomonas syzygii, Pseudomonas pickettii, and blood disease bacterium by partial $16 \mathrm{~S}$ sequencing: Construction of oligonucleotide primers for sensitive detection by polymerase chain reaction. J. Gen. Microbiol. 139:15871594.

54. Stewart, M. H., Wolfe, R. L., and Means, E. G. 1990. Assessment of the bacteriological activity associated with granular activated carbon treatment of drinking water. Appl. Environ. Microbiol. 56:3822-3829.

55. Strider, D. L., Jones, R. K., and Haygood, R. A. 1981. Southern bacterial wilt of geranium caused by Pseudomonas solanacearum. Plant Dis. 65:52-53.

56. Sulzinski, M. A., Moorman, G. W., Schlagnhaufer, B., and Romaine, C. P. 1997. A simple DNA extraction method for PCR-based detection of Xanthomonas campestris pv. pelargonii in geraniums. J. Phytopathol. 145:213-215.

57. Swanson, J. K., Yao, J., Tans-Kerstn, J., and Allen, C. 2005. Behavior of Ralstonia solanacearum race 3 biovar 2 during latent and active infection of geranium. Phytopathology 95:136-143.

58. Timms-Wilson, T. M., Bryant, K., and Bailey, M. J. 2001. Strain characterization and 16S-23S probe development for differentiating geographically dispersed isolates of the phytopathogen Ralstonia solanacearum. Environ. Microbiol. 3:785-797.

59. Tusiime, G., Adipala, E., Opio, F., and Bhagsari, A. S. 1998. Weeds as latent hosts of Ralstonia solanacearum in highland Uganda: Implications to development of an integrated control package for bacterial wilt. Pages 413-419 in: Bacterial Wilt Disease: Molecular and Ecological Aspects. P. Prior, C. Allen, and J. Elphinstone, eds. Springer-Verlag, Berlin.

60. van Elsas, J. D., Kastelein, P., de Vries, P. M., van Overbeek, L. S. 2001. Effects of ecological factors on the survival and physiology of Ralstonia solanacearum bv. 2 in irrigation water. Can. J. Microbiol. 47:842-854.

61. van Elsas, J. D., Kastelein, P., van Bekkum, P., van der Wolf, J. M., de Vries, P. M., and van Overbeek, L. S. 2000. Survival of Ralstonia solanacearum biovar 2 , the causative agent of potato brown rot, in field and microcosm soils in temperate climates. Phytopathology 90:1358-1366.

62. Weller, S. A., Elphinstone, J. G., Smith, N. C., Boonham, N., and Stead, D. E. 2000. Detection of Ralstonia solanacearum strains with a quantitative, multiplex, real-time, fluorogenic PCR (TaqMan) assay. Appl. Environ. Microbiol. 66:2853-2858.

63. Wenneker, M., Verdel, M. S. W., Groeneveld, R. M. W., Kempenaar, C., van Beuningen, A. R., and Janse, J. D. 1999. Ralstonia (Pseudomonas) solanacearum race 3 (biovar 2) in surface water and natural weed hosts: First report on stinging nettle (Urtica dioica). Eur. J. Plant. Pathol. 105:307-315.

64. Williamson, L., Nakaho, K., Hudelson, B., and Allen, C. 2002. Ralstonia solanacearum race 3 , biovar 2 strains isolated from geranium are pathogenic on potato. Plant Dis. 86:987-991.

65. Wood, J. R., Breckenridge, K., and Chard, J. M. 2002. Eradicating Ralstonia solanacearum from Scottish rivers. Page 31 in: Abstr. 3rd Int. Bacterial Wilt Symp. (IBWS), Nelspruit. Tobacco and Cotton Research Institute, Rustenberg, South Africa.

66. Wu, Y., Clevenger, T., and Deng, B. 2005. Impacts of goethite particles on UV disinfection of drinking water. Appl. Environ. Microbiol. 71:41404143.

67. Yabuuchi, E., Kosako, Y., Yano, I., Hotta, H., and Nishiuchi, Y. 1995. Transfer of two Burkholderia and an Alcaligenes species to Ralstonia gen. nov. Proposal of Ralstonia pickettii (Ralston, Palleroni and Doudoroff 1973) comb. nov.: Ralstonia solanacearum (Smith 1896) comb. nov. and Ralstonia eutropha (Davis 1969) comb. nov. Microbiol. Immunol. 39:897-904

68. Zhao, L., and Matthews, K. R. 2000. Influence of starvation, temperature, and $\mathrm{pH}$ on culturability of Escherichia coli O157:H7. J. Food Safety 20:193-208. 